\title{
A rare cause of neck swelling in a child
}

\author{
Abhimanyu K Niswade, Vijaya Sarathi, Saumil Desai, Pawan Kalamdani
}

Department of Pediatrics, Government Medical College, Nagpur, Maharashtra, India

\section{Correspondence to}

Dr Vijaya Sarathi, drvijayasarathi@gmail.com
To cite: Niswade AK, Sarathi V, Desai $S$, et al. BMJ Case Rep Published online: [please include Day Month Year] doi:10.1136/ bcr-2012-008444

\section{DESCRIPTION}

A 6-year-old boy who presented with sore throat had bilateral swellings in the submandibular regions (figure 1A). Surprisingly the swellings were pulsatile. Detailed history revealed generalised hypotonia during infancy with motor developmental delay. $\mathrm{He}$ had undergone sternotomy for closure of a large atrial septal defect at the age of 4 years. On examination he had lean built with long face, high arched palate, large ears, sternotomy scar on the chest (figure 1B) and bilateral inguinal herniae. There was mild increase in skin elasticity but no joint hyperextensibility. There was no cleft palate or bifid uvula. Family history revealed exactly similar features in the younger brother. MR angiogram of neck showed multiple tortuosities of bilateral common carotid and bilateral vertebral arteries (figure 1C).

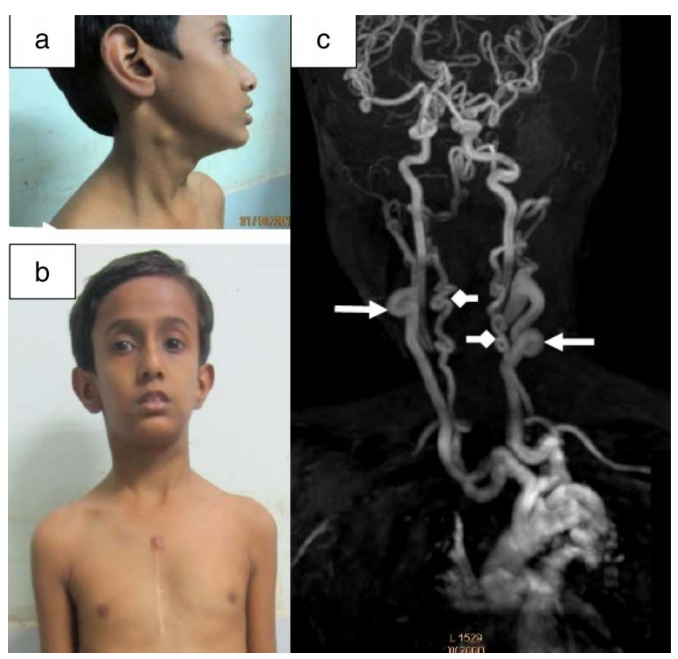

Figure 1 Clinical photograph of the patient showing right-sided neck swelling (A) with long slender face and sternotomy scar (B) and MR angiogram of major neck vessels showing marked tortuosities of bilateral carotid and vertebral arteries (C).
Arterial tortuosity syndrome and Loyes-Dietz syndrome are the closest differential diagnoses for this child. Arterial tortuosity syndrome occurs due to mutation in the gene (SLC2A10) encoding for glucose transporter GLUT10 whereas Loyes-Dietz syndrome occurs due to mutation in transforming growth factor $\beta$-receptor (TGFBR) 1 or $2 .{ }^{1}{ }^{2}$ Differentiation of these two conditions only on the basis of clinical grounds is not possible and requires genetic analysis for mutations in SLC2A10, TGFBR1 and TGFBR2. However, we could not obtain genetic analysis of our patient.

The most common vascular swelling in the neck of children is an aneurysm due to congenital, mycotic or post-traumatic reasons. ${ }^{3}$ As in our case, arterial tortuosities could be rare causes of vascular swellings in neck of children.

\section{Learning points}

- Arterial tortuosity could be a rare cause of vascular swelling in the neck of children.

- It is very essential to identify the vascular swellings in children to avoid disastrous attempts of aspiration or biopsy.

\section{Competing interests None. \\ Patient consent Obtained.}

Provenance and peer review Not commissioned; externally peer reviewed.

\section{REFERENCES}

1 Ritelli $M$, Drera B, Vicchio $M$, et al. Arterial tortuosity syndrome in two Italian paediatric patients. Orphanet J Rare Dis 2009;4:20.

2 Drera B, Ritelli M, Zoppi N, et al. Loeys-Dietz syndrome type I and type II: clinical findings and novel mutations in two Italian patients. Orphanet J Rare Dis 2009:4:24.

3 Pourhassan S, Grotemeyer D, Fokou M, et al. Extracranial carotid arteries aneurysms in children: single-center experiences in 4 patients and review of the literature. J Pediatr Surg 2007:42:1961-8.

Copyright 2013 BMJ Publishing Group. All rights reserved. For permission to reuse any of this content visit http://group.bmi.com/group/rights-licensing/permissions.

BMJ Case Report Fellows may re-use this article for personal use and teaching without any further permission.

Become a Fellow of BMJ Case Reports today and you can:

- Submit as many cases as you like

- Enjoy fast sympathetic peer review and rapid publication of accepted articles

- Access all the published articles

- Re-use any of the published material for personal use and teaching without further permission

For information on Institutional Fellowships contact consortiasales@bmjgroup.com

Visit casereports.bmj.com for more articles like this and to become a Fellow 